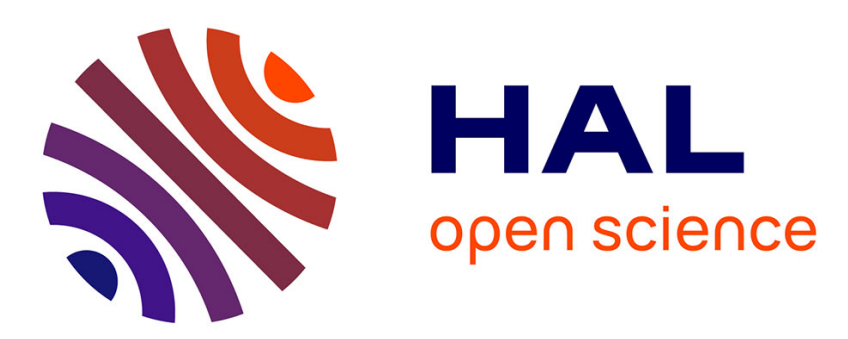

\title{
MALDI Imaging of Formalin-Fixed Paraffin-Embedded Tissues: Application to Model Animals of Parkinson Disease for Biomarker Hunting.
}

J. Stauber, R. Lemaire, M. Wisztorski, Julien Franck, Bonnel David, R. Day, I. Fournier, M. Salzet

\section{To cite this version:}

J. Stauber, R. Lemaire, M. Wisztorski, Julien Franck, Bonnel David, et al.. MALDI Imaging of Formalin-Fixed Paraffin-Embedded Tissues: Application to Model Animals of Parkinson Disease for Biomarker Hunting.. Journal of Proteome Research, 2008, 7 (7), pp.969-978. hal-00268379

\section{HAL Id: hal-00268379 \\ https://hal.science/hal-00268379}

Submitted on 9 Apr 2008

HAL is a multi-disciplinary open access archive for the deposit and dissemination of scientific research documents, whether they are published or not. The documents may come from teaching and research institutions in France or abroad, or from public or private research centers.
L'archive ouverte pluridisciplinaire HAL, est destinée au dépôt et à la diffusion de documents scientifiques de niveau recherche, publiés ou non, émanant des établissements d'enseignement et de recherche français ou étrangers, des laboratoires publics ou privés. 


\title{
MALDI IMAGING OF FFPE TISSUES: APPLICATION TO MODEL ANIMALS OF PARKINSON DISEASE FOR BIOMARKER HUNTING
}

\author{
Stauber $\mathrm{J}^{1 \zeta}$., Lemaire R. ${ }^{1 \zeta}$, Franck J. ${ }^{1}$, Bonnel $\mathrm{D}^{1}$, Croix $\mathrm{D} .^{1}$, \\ Day R. ${ }^{2}$, M. Wisztorski, Fournier . $^{1^{*}}$, Salzet $M .^{{ }^{* *}}$
}

1 : Université des Sciences et Technologies de Lille, FRE-CNRS 2933, MALDI Imaging Team, Laboratoire de Neuroimmunologie des Annélides, IFR 147, Cité Scientifique, 59655 Villeneuve d'Ascq Cedex, France

2 : Université de Sherbrooke, Département de Pharmacologie, Faculté de médecine, Sherbrooke, Québec, J1H 5N4, Canada

\begin{abstract}
:
A common technique for the long term storage of tissues in hospitals and clinical laboratories is preservation in formalin-fixed paraffin-embedded (FFPE) blocks. Such tissues stored for more than five years have not been useful for proteomic studies focused on biomarker discovery. Recently, MS-based proteomic analyses of FFPE showed positive results on blocks stored for less than 2 days. However, most samples are stored for more than one year, and thus our objective was to establish a novel strategy using as a model system 6-hydroxydopamine (6OHDA) treated rat brain tissues stored in FFPE blocks for more than 9 years. We examined MALDI tissue profiling combining the use of automatic spotting of MALDI matrix with in situ tissue enzymatic digestion. On adjacent sections, the identification of compounds is carried by in situ tissue digestion followed by nanoLC/MS-MS analysis. The combination of these approaches provides MALDI direct analysis, MALDI/MS imaging as well as the localization of a large number of proteins. This method is validated since the analyses confirmed that ubiquitin, transelongation factor 1 , hexokinase and the Neurofilament $M$ are down-regulated as previously

$\zeta:$ Equal contribution

*: co-corresponding author
\end{abstract}


shown in human or Parkinson animal models. In contrast, peroxidoredoxin 6, F1 ATPase and enolase are up-regulated. In addition, we uncovered three novel putative biomarkers, the Trans elongation Factor 1 (eEF1) and the Collapsin response mediator 1 and 2 from protein libraries. Finally we validate the CRMP-2 protein using immunocytochemistry and MALDI imaging based on the different ions from trypsic digestion of the protein. The access to archived FFPE tissue using MALDI profiling and imaging opens a whole new area in clinical studies and biomarkers discovery from hospital biopsy libraries.

Keywords: MALDI direct analysis, MALDI Imaging, FFPE tissues, Parkinson, biomarkers 


\section{INTRODUCTION}

Parkinson's disease (PD) is the second most common neurological disease after Alzheimer's disease. PD is characterized by a selective degeneration of dopaminergic neurons in the substantia nigra pars compacta and by cytoplasmic inclusions (Lewy Bodies) where specific proteins are stored like the $\alpha$-synuclein ${ }^{1}$. The clinical symptoms are severe motor dysfunctions, including rigidity, postural imbalance, slowness of movements, and uncontrollable tremor. Mutations in genes encoding $\alpha$-synuclein, parkin and ubiquitin carboxy-terminal hydrolase L1 (UCH L1) have been identified in sporadic familial forms of $\mathrm{PD}^{2}$. Several proteomic studies using 2D gel analyses in animal models and humans have identified biomarkers implicated in this pathology, 4,-7 (Table 1). In Parkin knockdown models, pyruvate dehydrogenase; $\mathrm{NADH}$ ubiquinone oxyreductase $30 \mathrm{kDa}$, cytochrome c oxydase, peroxiredoxin 1,2 and 6 , lactoylglutathione lyase, vacuolar protein sorting 29, crystalline chain b and heterogeneous nuclear ribonucleoprotein 1 are all down regulated ${ }^{4}$. Similarly, in 6-OHDA animal models ${ }^{8}$, as well as in humans, $\alpha$-enolase, $\beta$-actin, Lasp- 1 , neurofilament triplet $L$ and $M$ are also down-regulated ${ }^{3-6}$. In contrast, human peroxiredoxin 2 , complexin I, fatty acid binding protein, $\mathrm{L}$ type calcium chanel $d$ subunit, mitochondrial complex III and ATP synthase D chain are upregulated ${ }^{5}$. These results have been confirmed by Strey et al. ${ }^{7}$ in SOD1 gene studies, where $\alpha$ enolase as well as HSP25, HSP27, phosphatidyl insitol transfer protein, apoliprotein E and ferritin heavy chain are up-regulated. These contradictory studies for peroxidoxin 2 or profilin show the difficulty to get real biomarkers from these classical techniques. Molecular profiling of proteins and peptides can be performed directly on or near the surface of brain tissue sections with high specificity and sensitivity by utilizing matrix-assisted laser desorption ionization mass spectrometry (MALDI MS). This technique was first introduced by Caprioli et al. ${ }^{9}$ and adapted in other studies ${ }^{10}$. The first tissue profiling studies on 6-OHDA Parkinson model have been performed by Per Andrén group ${ }^{11}$. From their studies, calmodulin, cytochrome c, cytochrome $\mathrm{c}$ oxydase appear to be down-regulated with the exception of ubiquitin ${ }^{11}$.

In this study, we have been interesting by looking to Parkinson 's biomarkers using 6OHDA injected rat as model animals. Because brains available for this study has been stored after formalin fixation and paraffin embedding (FFPE) over 9 years more direct strategy was to perform in situ tissue enzymatic digestion prior to analysis. Indeed, formalin fixation induces proteins cross-linking inside the tissue by formation of methylene bridges. If such samples are extremely stables along the time and allow for high preservation of tissue integrity at the ultra cellular level, they raise analytical difficulties by the formation of a global protein network. Thus, 
enzymatic digestion gives the opportunity for retrieving small proteins pieces that are possible to be analyzed by conventional technologies. Proteins identification and localization was obtained using two different and complementary strategies that are MALDI MS direct profiling of tissues and imaging with nanoLC-nanoESI MS. First strategy allows for quickly observing variation in proteins abundances looking to their digestion peptides by comparison of model animals brains with control brains whereas second strategy allow high throughput identification of proteins including proteins of interest. Such combined approach as allowed us to confirmed that Hexokinase and Neurofilament $M$ proteins are down-regulated whereas by contrast, Collapsin Response Mediator Proteins 1 and 2 (CRMP1 and CRMP2), Peroxidoredoxine 6, F1 ATPase, Ubiquitin and $\alpha$-Enolase are up-regulated. Moreover, we also uncovered that the Trans elongation Factor 1 (eEF1) is down-regulated.. 


\section{EXPERIMENTAL}

\section{Material}

--cyano-4-hydroxycinnamic acid (HCCA), 2,5 dihydroxibenzoic acid (2,5-DHB), ammonium bicarbonate, trisma base, toluene, ethanol, Angiotensin II, Des-Arg-Bradykinin, Substance P, ACTH 18-39, ACTH 7-38 and bovine Insulin were obtained from Sigma-Aldrich and used as provided. Trypsin was from Promega. Trifluoroacetic acid (TFA) was purchased from Applied Biosystems. Acetonitrile p.a. and methanol p.a. from J.T. Baker.

\section{Animal Surgery and Treatment.}

Wistar male rats (180-200 g) were anesthetized with pentobarbital (50 mg/kg, i.p.) and infused over $8 \mathrm{~min}$ with $6-\mathrm{OHDA}$ ( $8 \mathrm{mg}$ in $4 \mathrm{ml}$ of $0.05 \%$ ascorbic acid in saline) at coordinates A $523.8 \mathrm{~mm}$, L $51.5 \mathrm{~mm}, \mathrm{H} 528.5 \mathrm{~mm}^{12}$.

\section{Tissue fixation}

Rats were sacrificed $4 \mathrm{~h}$ after the last drug injection. Their brains were removed and fixed for $40 \mathrm{~min}$ at $48^{\circ} \mathrm{C}$ in $4 \%$ paraformaldehyde. The accuracy of the 6-OHDA lesion was checked by immunocytochemistry with an anti-tyrosine hydroxylase antibody according to a previously published procedure ${ }^{12}$. These brain tissue blocks were then stored in a box at room temperature 9 years before used in this experimental plan procedure.

\section{Tissue dewaxing}

Tissue sections of $10 \mu \mathrm{m}$ were obtained using a microtome (E.Leitz, Westlard, Germany) and applied onto ITO (Indium Teen Oxided) one side coated conductive glass slides. Paraffin was removed by 2 baths of 5 minutes of toluene and lightly rehydrated with graded ethanol $\left(100^{\circ}, 96^{\circ}, 70^{\circ}\right.$ and $\left.30^{\circ}\right)$ bathes before drying at room temperature.

\section{In situ Trypsin digestion}

For MALDI direct analysis, $2 \mu \mathrm{L}$ of enzyme (trypsin $0.033 \mu \mathrm{g} / \mu \mathrm{L}$ in $25 \mathrm{mM}$ Tris buffer $\mathrm{pH}$ 7.4) was added at different spots on the tissue to obtain representative proteins/peptides profiles. The digest is performed at room temperature; the tissue is covered with a cap to decrease liquid evaporation. Each 10 minutes, enzyme solution is added on the same spots. Digestion is stopped by rinsing the tissue with $80 \%$ cold ethanol $\left(-20^{\circ} \mathrm{C}\right)$ to remove salts. The sections are allowed to dry at room temperature. $30 \mu \mathrm{L}$ of matrix solution (HCCA $20 \mathrm{mg}$ in 
ACN: $\mathrm{H}_{2} \mathrm{O}$ TFA $0.1 \%(7: 3, \mathrm{v} / \mathrm{v})$ is then applied on the tissue using a micropipette in order to cover the whole tissue section and dried at room temperature.

For MALDI Imaging, Trypsin microspotting: spots of enzyme (trypsin at 0,05 $\mu \mathrm{g} / \mu \mathrm{L}$ in water) were performed using a high accurate position automatic Chemical Inkjet Printer (CHIP1000, Shimadzu Biotech, Kyoto, Japan). Thus, the whole tissue section was micro-spotted with enzyme following a regular raster of spots of $\sim 200 \mu \mathrm{m}$ size. The quantity of trypsin was after optimization set to $20 \mathrm{~nL}$ by 40 cycles of $500 \mathrm{pL}$ on each spot position in order to cover the surface of tissue. $40 \mathrm{~nL}$ of ionic matrix was then spotted on the same position as for the enzyme using 40 cycles of $500 \mathrm{pL}$. The matrix preparation was described previously (ref). Briefly, just prior to use, 4,8 uL of Aniline (1 eq.) was added to the matrix solution (HCCA $10 \mathrm{mg} / \mathrm{mL}$ in ACN/TFA 0,1\%, 6:4, v/v) and sonicated during 2 minutes.

For nanoLC-ESI MS analysis, on a section of $2 \mathrm{~cm}^{2}$, in situ enzymatic digestion is performed by adding $15 \mu \mathrm{L}$ of trypsin enzyme $(0.033 \mu \mathrm{g} / \mu \mathrm{L}$ in $25 \mathrm{mM}$ Tris buffer $\mathrm{pH} 7.4)$ for $1 \mathrm{H}$ hour at room temperature. After enzymatic digestion, purification of resulting digestion peptides was achieved by using reverse phase $\mathrm{C}_{8}$ coated silica magnetic beads (ClinProts ${ }^{\mathrm{TM}}$, Bruker Daltonics, Germany) according to the protocol of the manufacturer modified for tissues. For this, $15 \mu \mathrm{L}$ of binding solution was directly applied onto the tissue during 1 minute, then $15 \mu \mathrm{L}$ of magnetic bead was added on the section. Extraction occurred during 10 minutes. During this step, beads and digested products were mixed 3 times using a micropipette directly onto the tissue. Digestion solution and beads were, then, deposited in a polypropylene tube and washed 3 times using $500 \mu \mathrm{L}$ of $\mathrm{H}_{2} \mathrm{O} /$ TFA $0.1 \%$. Peptides were eluted from the beads with $30 \mu \mathrm{L}$ of $\mathrm{ACN} / \mathrm{H}_{2} \mathrm{O}(1: 1, v / \mathrm{v})$ and solution was dried by vacuum centrifugation. For nano LC-MS/MS identification, peptides were re-dissolved in $\mathrm{H}_{2} \mathrm{O} / \mathrm{MEOH} 0.1 \%$ formic acid $(9: 1 \mathrm{v} / \mathrm{v})$ after elution and evaporation.

\section{Mass Spectrometry \\ MALDI MS direct analysis of tissue sections}

Spectra were acquired on a Voyager-DE STR mass spectrometer (Applied Biosystems, Framingham, MA, USA) with delayed extraction (DE) and a $337 \mathrm{~nm}$ pulsed nitrogen laser with a repeptition of $3 \mathrm{~Hz}$. External calibration was performed using a solution of standard peptides (bradykinin $1.6 \mu \mathrm{M}$, Substance $\mathrm{P} 1.6 \mu \mathrm{M}$, ACTH 18-39 $1.6 \mu \mathrm{M}$, ACTH 7-38 $3.2 \mu \mathrm{M}$, bovine Insulin $4.8 \mu \mathrm{M}$ and bovine Ubiquitin $4.8 \mu \mathrm{M}$ in $\mathrm{H}_{2} \mathrm{O}$ ). Slices were visualized in the mass 
spectrometer using a color CCD camera (SONY). Each spectrum is the result of the average of 200 laser shots of the area of interest.

MALDI MS direct analysis of tissue sections after in situ automatic trypsin digestion

Trypsin fingerprint experiments of FFPE tissue sections after in situ digestion of the whole tissue section were performed on an Ultraflex II TOF-TOF instrument (Bruker Daltonics, Bremen, DE) equipped with LIFT III cell and Smartbeam laser with a repetition rate up to $200 \mathrm{~Hz}$. For MS/MS experiments parameters were set as follow: laser repetition rate was $100 \mathrm{~Hz}$ with $33 \%$ attenuation, ion source voltages were respectively $8 \mathrm{kV}$ and $7.3 \mathrm{kV}$ on MALDI sample plate and $1^{\text {st }}$ electrode; LIFT cell was pulse from ground for electrode 1 and 2 to $19 \mathrm{kV}$ and in the last step electrode 3 was decrease to $3.2 \mathrm{kV}$; reflector end voltage was set to $29.5 \mathrm{kV}$ and mid-grid to $13.85 \mathrm{kV}$. Tryspin fingerprint protein identification in databanks were performed using the Biotools 3.0 software (Bruker Daltonics, Bremmen, DE) connected to Mascot search engine and interrogating the NCBI, Swissprot and ESTs databanks with Oxydation as Variable modification, Monoisotopic as mass values, a peptide mass tolerance \pm 0.1 Da with a peptide charge state of $1+$, max missed cleavages of 2 and number of queries of 300 .

\section{MALDI MSI}

For MALDI-MSI of 9 years stored fixed and paraffin embedded tissues, images were performed on an Ultraflex II TOF-TOF (Bruker Daltonics, Bremen, DE). After dewaxing, images were obtained in positive reflector mode after trypsin digestion and matrix deposition $20 \mathrm{~nL}$ of the mix was applied onto the tissue using a microspotting as explained above and dried at room temperature. Acquisition was realized using Smartbeam laser, with a repetition rate of $100 \mathrm{~Hz}$ and a spatial resolution of $100 \times 100 \mu \mathrm{m}$. For images reconstruction the Flexlmaging v2.0 software (Bruker Daltonics, Bremen, DE) was used. For positive mode, 12919 spots covering the whole slice with 500 laser shots per position were scanned. From each position the software measures an average mass spectrum with its coordinates on the slice.

\section{Nano LC-nanoESI-IT MS and MS/MS}

Analyses were performed on an ion trap mass spectrometer (LCQ deca XP plus, Thermo electron, Manchester, UK) equipped with a nano ESI ion source and on-line coupled to a nano HPLC system. $0.5 \mu \mathrm{L}$ of digest were injected with a Switchos Autosampler (Dionex corporation) and separation performed on a C18 silica bonded stationary phase $(75 \mu \mathrm{m}$ i.d., $150 \mathrm{~mm}$ long, $3 \mu \mathrm{m} 100 \AA$ pore size, Dionex). Samples were washed for 2 minutes at $10 \mu \mathrm{L} / \mathrm{min}$ with $100 \%$ mobile phase $\mathrm{A}(95 \% \mathrm{H} 2 \mathrm{O}, 5 \% \mathrm{ACN} 0.1 \%$ formic acid). Peptides were then eluted using a linear gradient of $1 \% /$ min mobile phase $\mathrm{B}(\mathrm{ACN} 80 \%, \mathrm{H} 2 \mathrm{O} 20 \%$, formic acid $0.08 \%)$ for 70 minutes at 
a flow rate of $0.2 \mu \mathrm{L} / \mathrm{min}$. The $L C Q$ was operated in a data dependent MS/MS mode in which one MS full scan was followed by one MS/MS scan on the most abundant peptide ion. Collision energy was set to $35 \%$. The heated capillary temperature and electrospray voltage were $160^{\circ} \mathrm{C}$ and $1.5 \mathrm{kV}$ respectively.

Protein identification was performed under MASCOT sequence query search program using SwissProt database filtered for the taxonomy "Rattus norvegicus". A tolerance of $2 \mathrm{Da}$ for peptide and 0.8 Da for MS/MS was set. Only protein sequences with MOWSE score higher than 36 (indicating significant homology or identity) and identified in several samples representing at least 2 significants MS/MS were considered. Methionine oxydation and acetylation of $\mathrm{N}$ terminal were defined as variable modification.

\section{RESULTS AND DISCUSSION}

Brain tissue blocks of five 6-OHDA treated versus 5 untreated rats where systematically studied and compared for biomarkers hunting. The FFPE brains had been stored for 9 years before use in the present report. Formalin fixation provokes the formation of protein-nucleic acid and protein-protein cross-linking in the intracellular environment arising from the reactivity of formaldehyde with the side-chains of lysyl, argininyl, tyrosyl, aspartyl, histidyl, and seryl residues ${ }^{13}$. The methylene bonds are difficult to break without destroying peptide backbone. To solve this problem, we used endopeptidases directly on tissue sections to break down the protein network and retrieve digestion peptides that can also be used for protein identification.

In a first strategy, digestion of the whole tissue section followed by extraction of the resulting solution form the tissue, purification, separation and analysis on a nanoLC-nanoESI-IT system is used. By plotting intensity vs. retention time vs. M/Z differences between our two physiological states can easily be observed. Comparison of nanoLC profiles from Parkinson animal models compared to controls reflects the presence of numerous proteins among which most are common and a few of them are specific to each condition has exemplified by the plots presented Figure 1. For each peak observed on the TIC chromatogram an MS is performed followed by MS/MS on the most abundant ions. More than 100 hundreds proteins can be identified for each type of samples using this method. Among all the identified proteins some of the proteins are known to be present a low concentration. Interestingly, such FFPE tissue seem to bring an easier access to lowly abundant proteins than samples stored frozen without treatment, probably because the protein cross-linking network render some proteins more accessible that they are in the normal tissue. 
In a second step we were interested by comparing the results of the classical proteomic "Bottom-up" approach with the direct analysis by MALDI. MALDI direct analysis of the tissue after digestion allows for identifying several proteins by peptide mass fingerprint and confirmation of the modulation of the previously identified proteins. As given in example in Figure 2 for Neurofilament Triplet M protein is clearly observed in the control samples whereas this protein is almost not observed in the 6-OHDA treated samples. Table 2 gives examples of proteins that where identified in the MALDI direct analysis approach. Considering the sub cellular localization of these compounds we can confirm that MALDI direct analysis after in situ digestion allows the detection of proteins from different compartment such as cytosol, nuclear envelope and cytoskeleton and not just from the cell surface. Various functional proteins were detected including enzymes or signal transduction molecules or regulators. The technique allows the detection of very high mass compounds directly from the tissue like vimentin, neuromodulin, neurogenesin.

Considering, the data obtained by MALDI and ESI; in the case of the animal treated with 6OHDA, the results obtained (Table 3 ) are in agreement with those obtained from 6-OHDA rat brain frozen tissue section by Pierson et al. ${ }^{11}$ (Table 1). 6-OHDA is known to inhibit the mitochondrial transport chain and this, along with the resulting production of reactive oxygen species contributing to neuronal death ${ }^{14}$. This agent appears to induce neuronal death by activating transcription as well as DNA repair enzymes ${ }^{15}$. When activated, the signal transcription pathways initiated by PERK and IRE1a induce a characteristic set of genes encoding ER chaperones and nuclear transcription factors that lead to reduction of ER stress or to death ${ }^{16}$.

Based on these data, comparison of the proteins present or absent in both conditions revealed the presence of specific proteins which have been identified in the Parkinson model, such as Hexokinase (2-7-1-1), Neurofilament M protein, Peroxidoxin 6, F1 ATPase and $\alpha$-Enolase (Tables 1 and 3).

Neurofilament $M$ protein has been described as down-regulated ${ }^{17} 5$ and its down regulation is correlated with decreased mRNA during the disease and is dependant upon disease severity ${ }^{17}$. Our results using direct analysis of FFPE tissues support these findings.

Due to 6-OHDA treatment provoking oxidative stress, several molecules have been found to be up-regulated under these conditions, such as Peroxydoxin 6, known as an anti-oxidative protein. Similar results where found Strey et al. ${ }^{7}$ using classical proteomic studies. In contrast, peroxydoxin 2 is described as being down-regulated in the parkin knockout model but is upregulated in human Parkinson's disease studies. These data reaffirm the need to consider multiplex biomarkers for 
pathology. $\alpha$-enolase was also increased in our study as previously observed elsewhere in the case of Parkinson's or Alzheimer's disease ${ }^{3,7}$ ). This molecule is known to be the target of specific oxidation or nitrozation ${ }^{3}$. We also observed upregulation of F1 ATPase as previously demonstrated by Seo et al. ${ }^{18}$

The ubiquitin complex was observed to be upregulated in our study on FFPE tissue as shown by Pierson et al. ${ }^{11}$. It is known that high levels of ubiquitin and ubiquinated proteins are present in Lewy bodies indicating that protein degradation is impaired in PD ${ }^{2}$. Proteins conjugated with a chain of ubiquitin moieties are targeted to the ubiquitin-proteasome system complex, where they undergo proteolytic degradation. Genetic studies of PD have identified mutations in the genes coding for proteins involved in the ubiquitin-proteasome degradation pathway ${ }^{19,20}$.

Interestingly, results obtained from 6-OHDA treated animals after trypsin digestion and nano-LC nanoESI-IT MS and MS/MS experiments revealed a novel biomarker, the collapsin response mediator protein 2. Figure 3 presents the results of identification for CRMP2 proteins. Several digestion fragments of this protein are found in nanoESI (Figure 3a) and databanks interrogation using the MS/MS experiments confirm this identification with attribution of the MS/MS data (as exemplified for ion at $\mathrm{m} / \mathrm{z}$ 508.59) that is clearly consistent with ion fragment series expected for such instruments (Figure 3b). MALDI direct analysis experiments give good agreement with the previous identification even if digestion fragments observed in MALDI are different from those observed in nanoESI exection of one peptide as highlighted in the CRMP2 sequence (Figure 3c). MS/MS performed directly on the tissue section in MALDI confirmed that the observed fragments would be consistents with digestion peptides of CRMP2 protein. Globally, all the data combined together give identification to this up-regulated protein as the CRMP2 splice variant B of the CRMP2 protein (Rattus norvegicus, P47492).

Two splices variants have been recently found ${ }^{21}$. Indeed, the CRMP2A is the long Nterminal isoform $(75 \mathrm{kDa})$ and induce oriented microtubule patterns in cultured fibroblasts, a pattern also observed in axons. Conversely, CRMP2B, the shortest variant (64 kDa) induces disorientation of microtubule patterns in cultured fibroblasts and reduces axon length when overexpressed in retinal explants ${ }^{21}$.. In adult brain, it is known that expression of CRMPs is dramatically down regulated ${ }^{22}$. In our study, an increase in of CRMP2B in 6-OHDA treated animals has been observed which is in agreement with previous molecular data. ${ }^{23}$. To go deeper inside the understanding of the role CRMP2 we have consecutively performed MALDI Imaging of CRMP2 in the 6-OHDA treated samples to obtain the localization of the protein. Figure 3 presents the MALDI molecular images obtained from such samples and reconstructed using different ions corresponding to different digestion fragments of the protein. All these ions globally 
present an equivalent localization in the rat brain section, even if some of them present more contrasted images. Last image is a composite image taking into account the signal of all ions corresponding to identify digestion fragments of CRMP2 for a global view. The most striking feature is the important localization of the protein is very specific regions of the brain with a highly contrasted signal. This is especially true for the corpus callosum were ions are always found to be very intense. Figure 4 present the map of the corresponding section and compared the MALDI images from the -6OHDA treated animals to the expression of the CRMP2 mRNA in normal adult mouse. As found in the literature for the rat, this variant of CRMP2 is normally not present in the corpus callosum. It is located predominantly in dendrites of specific neuronal populations, such as cortical pyramidal neurons, hippocampal CA1 pyramidal cells, or Purkinje cerebellar cells ${ }^{24}$. Thus localization in Corpus callosum is in line with an involvement in neurodegenerative diseases. In fact, Corpus callosum is known to be a brain area implicated in dementia in lot of neurodegenerative diseases ${ }^{25}$.

Thus, in PD, the CRMP (intracellular protein mediating Semaphorin3A) and the mitochondrial stress protein HSP60 mRNA encoding these proteins are up-regulated. Antibodies directed against collapsin-1 (Sema3A, that functions in signaling growth cone collapse, chemorepulsion and neuronal apoptosis during early development of the central nervous system) provided marked and prolonged protection of several neuronal cell types from dopamine-induced apoptosis ${ }^{23}$. It has been hypothesized that these proteins are positive mediators of DA-induced neuronal apoptosis in PD. In PD, nigral neuronal death could be due to excessive oxidative stress generated by auto- and enzymatic oxidation of the endogenous neurotransmitter dopamine (DA), the formation of neuromelanin and the presence of high concentrations of iron. DA toxicity is mediated through its oxidative metabolites, whereas thiolcontaining antioxidants provided marked protection against DA toxicity, ascorbic acid accelerated DA-induced death. In Alzheimer's disease, the CRMP-2 is know to be implicated in neurite degeneration, acting on the assembly and polymerization of microtubules ${ }^{26}$. Accumulation of Sema3A overlaps the appearance of phosphorylated MAP1B and tau in many neurons, suggesting that Sema3A signaling at some level may be coupled to these previously identified cytoskeletal markers of neurodegeneration ${ }^{27}$. The hippocampus of patients with $A D$ express phosphorylated MAP1B, collapsin-response mediator protein 2 (CRMP-2), Plexins A1 and $A 2$, and a processed form of Sema3A ${ }^{27}$.,

Thus, we speculate that CRMP factors are good biomarkers for neurodegenerative diseases like PD or AD. 
While our methodology is validated by confirming previously discovered molecules implicated in PD, we have also uncovered previously undescribed changes, such as the downregulation of Trans-elongation factor 1 (eEF1) in 6-OHDA samples. Studies on regulatory factors of heat shock factor (HSF-1) modulation and their involvement in the age-associated attenuation have demonstrated an attenuated response to stress which is characteristic of senescence. Heat shock (HS), a significant form of stress, is delayed and reduced in aging organisms. The proteins I-HSF [HSF inhibitor], eEF1 and a large non-coding RNA (HSR) participate in regulation and activation of HSF-1 in early stages of heat shock gene transcription. It is proposed that structural changes in any one or combination of these factors in response to heat shock may contribute to the age-associated attenuation in response to stress ${ }^{28}$. These results are in agreement with the fact that 6-OHDA treatment provokes a down regulation of the eEF1. Moreover, 6-OHDA provokes an oxidative stress stimulating HSP expression as demonstrated by Strey at al. ${ }^{7}$ and as it is down regulated in these conditions. Finally, eEF1 is present in the dendrites of neurons that exhibit synaptic plasticity and its translation is locally regulated ${ }^{29}$. In the hippocampus, the dendritic mRNAs is highly expressed in cell bodies and is also concentrated in the zone of termination of commissural/associational afferents in the inner molecular layer, suggesting that mRNA localization is in some way related to the distribution of different types of synapses ${ }^{30}$. In the case of the 6-OHDA model, this treatment provokes a decrease of synaptic plasticity and thus a down regulation of eEFI levels.

In conclusion, using nine year old FFPE tissues, we confirmed that molecules acting in oxidative stress are regulated as already demonstrated in various proteomic studies on human or fresh frozen tissues in 6-OHDA animal model. New biomarkers were found such as eEF1 and CRMP. This confirms the high interest to use this FFPE tissues stored in hospital tissue libraries for biomarkers hunting or validation in the case of clinical studies.

\section{ACKNOWLEDGEMENTS}

Supported by grants from Centre National de la Recherche Scientifique (CNRS), Ministère de L'Education Nationale, de L'Enseignement Supérieur et de la Recherche (ACI Jeunes Chercheurs ACI JC4074 to I. Fournier), the Canadian Institutes of Health Research (CIHR to R. Day and M. Salzet). Also supported by a collaboration agreement between Shimadzu and the Laboratoire de Neuroimmunologie des Annélides. The authors would also like to thank A. Page and C. Rolando of the Proteomic Plateform of USTL. 


\section{REFERENCES}

1. Beal, M. F.; Hantraye, P., Novel therapies in the search for a cure for Huntington's disease. Proc Natl Acad Sci U S A 2001, 98, (1), 3-4.

2. Giasson, B. I.; Lee, V. M., Are ubiquitination pathways central to Parkinson's disease? Cell 2003, 114, (1), 1-8.

3. De Iuliis, A.; Grigoletto, J.; Recchia, A.; Giusti, P.; Arslan, P., A proteomic approach in the study of an animal model of Parkinson's disease. Clin Chim Acta 2005, 357, (2), 202-9.

4. Palacino, J. J.; Sagi, D.; Goldberg, M. S.; Krauss, S.; Motz, C.; Wacker, M.; Klose, J.; Shen, J., Mitochondrial dysfunction and oxidative damage in parkin-deficient mice. $J$ Biol Chem 2004, 279, (18), 18614-22.

5. Basso, M.; Giraudo, S.; Corpillo, D.; Bergamasco, B.; Lopiano, L.; Fasano, M., Proteome analysis of human substantia nigra in Parkinson's disease. Proteomics 2004, 4, (12), 3943-52.

6. $\quad$ Basso, M.; Giraudo, S.; Lopiano, L.; Bergamasco, B.; Bosticco, E.; Cinquepalmi, A.; Fasano, M., Proteome analysis of mesencephalic tissues: evidence for Parkinson's disease. Neurol Sci 2003, 24, (3), 155-6.

7. Strey, C. W.; Spellman, D.; Stieber, A.; Gonatas, J. O.; Wang, X.; Lambris, J. D.; Gonatas, N. K., Dysregulation of stathmin, a microtubule-destabilizing protein, and upregulation of Hsp25, Hsp27, and the antioxidant peroxiredoxin 6 in a mouse model of familial amyotrophic lateral sclerosis. Am J Pathol 2004, 165, (5), 1701-18.

8. Ungerstedt, U.; Ljungberg, T.; Steg, G., Behavioral, physiological, and neurochemical changes after 6-hydroxydopamine-induced degeneration of the nigrostriatal dopamine neurons. Adv Neurol 1974, 5, 421-6.

9. Caprioli, R. M.; Farmer, T. B.; Gile, J., Molecular imaging of biological samples: localization of peptides and proteins using MALDI-TOF MS. Anal Chem 1997, 69, (23), 4751-60.

10. Fournier, I.; Day, R.; Salzet, M., Direct analysis of neuropeptides by in situ MALDITOF mass spectrometry in the rat brain. Neuro Endocrinol Lett 2003, 24, (1-2), 9-14.

11. Pierson, J.; Norris, J. L.; Aerni, H. R.; Svenningsson, P.; Caprioli, R. M.; Andren, P. E., Molecular profiling of experimental Parkinson's disease: direct analysis of peptides and proteins on brain tissue sections by MALDI mass spectrometry. $J$ Proteome Res 2004, 3, (2), 289-95.

12. Tonnaer, J. A.; Lammers, A. J.; Wieringa, J. H.; Steinbusch, H. W., Immunohistochemical evidence for degeneration of cholinergic neurons in the forebrain of the rat following injection of AF64A-picrylsulfonate into the dorsal hippocampus. Brain Res 1986, 370, (1), 200-3.

13. Shi, S. R.; Imam, S. A.; Young, L.; Cote, R. J.; Taylor, C. R., Antigen retrieval immunohistochemistry under the influence of $\mathrm{pH}$ using monoclonal antibodies. $J$ Histochem Cytochem 1995, 43, (2), 193-201.

14. Grunblatt, E.; Mandel, S.; Youdim, M. B., Neuroprotective strategies in Parkinson's disease using the models of 6-hydroxydopamine and MPTP. Ann N Y Acad Sci 2000, 899, 262-73.

15. Herceg, Z.; Wang, Z. Q., Functions of poly(ADP-ribose) polymerase (PARP) in DNA repair, genomic integrity and cell death. Mutat Res 2001, 477, (1-2), 97-110.

16. Mori, K., Tripartite management of unfolded proteins in the endoplasmic reticulum. Cell 2000, 101, (5), 451-4. 
17. Liu, Q.; Xie, F.; Siedlak, S. L.; Nunomura, A.; Honda, K.; Moreira, P. I.; Zhua, X.; Smith, M. A.; Perry, G., Neurofilament proteins in neurodegenerative diseases. Cell Mol Life Sci 2004, 61, (24), 3057-75.

18. Seo, B. B.; Nakamaru-Ogiso, E.; Cruz, P.; Flotte, T. R.; Yagi, T.; Matsuno-Yagi, A., Functional expression of the single subunit NADH dehydrogenase in mitochondria in vivo: a potential therapy for complex I deficiencies. Hum Gene Ther 2004, 15, (9), 887-95.

19. Leroy, E.; Boyer, R.; Auburger, G.; Leube, B.; Ulm, G.; Mezey, E.; Harta, G.; Brownstein, M. J.; Jonnalagada, S.; Chernova, T.; Dehejia, A.; Lavedan, C.; Gasser, T.; Steinbach, P. J.; Wilkinson, K. D.; Polymeropoulos, M. H., The ubiquitin pathway in Parkinson's disease. Nature 1998, 395, (6701), 451-2.

20. Leroy, E.; Boyer, R.; Polymeropoulos, M. H., Intron-exon structure of ubiquitin cterminal hydrolase-L1. DNA Res 1998, 5, (6), 397-400.

21. Yuasa-Kawada, J.; Suzuki, R.; Kano, F.; Ohkawara, T.; Murata, M.; Noda, M., Axonal morphogenesis controlled by antagonistic roles of two CRMP subtypes in microtubule organization. Eur J Neurosci 2003, 17, (11), 2329-43.

22. Ricard, D.; Stankoff, B.; Bagnard, D.; Aguera, M.; Rogemond, V.; Antoine, J. C.; Spassky, N.; Zalc, B.; Lubetzki, C.; Belin, M. F.; Honnorat, J., Differential expression of collapsin response mediator proteins (CRMP/ULIP) in subsets of oligodendrocytes in the postnatal rodent brain. Mol Cell Neurosci 2000, 16, (4), 324-37.

23. Barzilai, A.; Zilkha-Falb, R.; Daily, D.; Stern, N.; Offen, D.; Ziv, I.; Melamed, E.; Shirvan, A., The molecular mechanism of dopamine-induced apoptosis: identification and characterization of genes that mediate dopamine toxicity. J Neural Transm Suppl 2000, (60), 59-76.

24. Bretin, S.; Reibel, S.; Charrier, E.; Maus-Moatti, M.; Auvergnon, N.; Thevenoux, A.; Glowinski, J.; Rogemond, V.; Premont, J.; Honnorat, J.; Gauchy, C., Differential expression of CRMP1, CRMP2A, CRMP2B, and CRMP5 in axons or dendrites of distinct neurons in the mouse brain. $J$ Comp Neurol 2005, 486, (1), 1-17.

25. Charrier, E.; Reibel, S.; Rogemond, V.; Aguera, M.; Thomasset, N.; Honnorat, J., Collapsin response mediator proteins (CRMPs): involvement in nervous system development and adult neurodegenerative disorders. Mol Neurobiol 2003, 28, (1), 51-64.

26. Gu, Y.; Hamajima, N.; Ihara, Y., Neurofibrillary tangle-associated collapsin response mediator protein-2 (CRMP-2) is highly phosphorylated on Thr-509, Ser-518, and Ser-522. Biochemistry 2000, 39, (15), 4267-75.

27. Good, P. F.; Alapat, D.; Hsu, A.; Chu, C.; Perl, D.; Wen, X.; Burstein, D. E.; Kohtz, D. S., A role for semaphorin $3 \mathrm{~A}$ signaling in the degeneration of hippocampal neurons during Alzheimer's disease. $J$ Neurochem 2004, 91, (3), 716-36.

28. Shamovsky, I.; Gershon, D., Novel regulatory factors of HSF-1 activation: facts and perspectives regarding their involvement in the age-associated attenuation of the heat shock response. Mech Ageing Dev 2004, 125, (10-11), 767-75.

29. Huang, F.; Chotiner, J. K.; Steward, O., The mRNA for elongation factor 1alpha is localized in dendrites and translated in response to treatments that induce long-term depression. J Neurosci 2005, 25, (31), 7199-209.

30. Zhong, J.; Zhang, T.; Bloch, L. M., Dendritic mRNAs encode diversified functionalities in hippocampal pyramidal neurons. BMC Neurosci 2006, 7, 17.

31. Takubo, H.; Shimoda-Matsubayashi, S.; Mizuno, Y., Serum creatine kinase is elevated in patients with Parkinson's disease: a case controlled study. Parkinsonism Relat Disord 2003, 9 Suppl 1, S43-6. 
32. Skold, K.; Svensson, M.; Nilsson, A.; Zhang, X.; Nydahl, K.; Caprioli, R. M.; Svenningsson, P.; Andren, P. E., Decreased striatal levels of PEP-19 following MPTP lesion in the mouse. $J$ Proteome Res 2006, 5, (2), 262-9.

33. Pastoris, O.; Dossena, M.; Foppa, P.; Catapano, M.; Ferrari, R.; Dagani, F., Biochemical evaluations in skeletal muscles of primates with MPTP Parkinson-like syndrome. Pharmacol Res 1995, 31, (6), 361-9.

34. Poon, H. F.; Frasier, M.; Shreve, N.; Calabrese, V.; Wolozin, B.; Butterfield, D. A., Mitochondrial associated metabolic proteins are selectively oxidized in A30P alphasynuclein transgenic mice--a model of familial Parkinson's disease. Neurobiol Dis 2005, 18, (3), 492-8. 


\section{FIGURE LEGENDS}

Figure 1: Comparison of $3 D$ Intensity vs. $M / Z$ vs. retention time plots reconstructed from the data collected on the nanoLC-nanoESI-IT MS experiments after in situ trypsin digestion and extraction of peptides for a) control animals and b) 6-OHDA treated model animals. First 3D view corresponds to retention time $0-60 \mathrm{~min}$ vs $\mathrm{M} / \mathrm{z} 700-800$ whereas second view corresponds to retention time 30-33 min vs. M/z 200-1800.

Figure 2: Superposition of six mass spectra obtained by MALDI direct analysis in the same region of FFPE tissue sections after in situ trypsin digestion for three 6-OHDA treated animals versus three control animals. Arrows indicate ion at $\mathrm{m} / \mathrm{z} 1770.3$ identified as a digestion fragment of Neurofilament Triplet M protein which is a potential biomarker.

Figure 3: MALDI molecular images reconstructed from the data collected after acquisition on a 6-OHDA treated rat brain section originally conserved after formalin fixation and paraffin embedding over 9 years after in situ automatic trypsin digestion. a) Image of ion at $\mathrm{m} / \mathrm{z} 643, \mathrm{~b}$ ) $\mathrm{m} / \mathrm{z} 728$, c) 1083 and d) composite image of all ions corresponding to digestion fragments of CRMP2 protein and detected in the MALDI experiment.

Figure 4: a) composite MALDI molecular image reconstructed using all detected digestion fragments of CRMP2 protein on a 6-OHDA treated FFPE tissue rat brain section after paraffin removal and in situ trypsin digestion. b) Optical image of the tissue section after automatic spotting of trypsin and solid ionic matrix HCCA/ANI, c) Map of the corresponding tissue section with different region indicated (Bregma Index) and d) Expression of Dpys 12 mRNA (coding for CRMP2 protein) in mouse brain (data from Allen Brain Atlas http://www.brain-map.org ) 
Table 1: Comparison of Parkinson Biomarkers identified using different proteomics approaches on different models

\begin{tabular}{|c|c|c|c|c|}
\hline Model & $\begin{array}{l}\text { Proteomic } \\
\text { Approach }\end{array}$ & Protein & Modification & References \\
\hline \multirow[t]{2}{*}{ Parkin -/- } & \multirow[t]{2}{*}{ 2D Gel } & $\begin{array}{c}\text { Pyruvate Deshydrogenase } \\
\text { NADH Ubiquinone Oxyreductase } 24 \mathrm{kDa} \\
\text { NADH Ubiquinone Oxyreductase } 30 \mathrm{kDa} \\
\text { Cytochrome c Oxydase } \\
\text { Peroxiredoxin } 1 \\
\text { Peroxiredoxin } 2 \\
\text { Peroxiredoxin } 6 \\
\text { Lactoylglutathione Lyase } \\
\text { Profilin } \\
\text { Vacuolor Protein Sorting } 29 \\
\alpha-\text { Crystalin Chain b } \\
\text { Heterogeneous Nuclear Ribonucleoprotein } 1 \\
\text { Lasp-1 }\end{array}$ & $\begin{array}{c}\text { Down-regulated } \\
\text { Up-regulated } \\
\text { Down-regulated } \\
\text { Down-regulated } \\
\text { Down-regulated } \\
\text { Down-regulated } \\
\text { Down-regulated } \\
\text { Down-regulated } \\
\text { Down-regulated } \\
\text { Down-regulated } \\
\text { Down-regulated } \\
\text { Down-regulated } \\
\text { Down-regulated }\end{array}$ & 4 \\
\hline & & $\begin{array}{c}\alpha-\text { enolase } \\
\beta \text { Actin }\end{array}$ & $\begin{array}{l}\text { Up-regulated } \\
\text { Down-regulated }\end{array}$ & 3 \\
\hline 6-OHDA & $\mathrm{MDA}^{*}$ & $\begin{array}{c}\text { Calmodulin } \\
\text { Cytochrome C } \\
\text { Cytochrome C oxydase } \\
\text { Ubiquitin } \\
\end{array}$ & $\begin{array}{l}\text { Down-regulated } \\
\text { Down-regulated } \\
\text { Down-regulated } \\
\text { Up-regulated } \\
\end{array}$ & 11 \\
\hline \multirow[b]{2}{*}{ Human } & \multirow[b]{2}{*}{ 2D Gel } & Serum Creatine Kinase & Up-regulated & 31 \\
\hline & & $\begin{array}{c}\text { Neurofilament Triplet L } \\
\text { Neurofilament Triplet M } \\
\text { Peroxiredoxin } 2 \\
\text { Mitochondrial Complex III } \\
\text { ATP Synthase D chain } \\
\text { Profilin } \\
\text { L Type Calcium Chanel d Subunit } \\
\text { Fattu Acid Binding Protein } \\
\text { PEP 19 }\end{array}$ & $\begin{array}{l}\text { Down-regulated } \\
\text { Down-regulated } \\
\text { Up-regulated } \\
\text { Up-regulated } \\
\text { Up-regulated } \\
\text { Up-regulated } \\
\text { Up-regulated } \\
\text { Up-regulated } \\
\text { Up-regulated }\end{array}$ & 5 \\
\hline MTP & MDA & $\alpha$-Enolase & Down-regulated & 32 \\
\hline $\begin{array}{c}\text { G93 A } \\
\text { (gene SOD1) }\end{array}$ & 2D Gel & $\begin{array}{c}\text { HSP } 25 \\
\text { HSP } 27 \\
\text { Phosphatidinylinositol Transger Protein a } \\
\text { Apolipoprotein E } \\
\text { Ferritin Heavy Chain }\end{array}$ & $\begin{array}{l}\text { Up-regulated } \\
\text { Up-regulated } \\
\text { Up-regulated } \\
\text { Up-regulated } \\
\text { Up-regulated }\end{array}$ & 7 \\
\hline
\end{tabular}

*MDA: MALDI Direct Analysis MS 
Table 2: Examples of proteins detected by MALDI direct analysis MS from the FFPE rat brain tissues after in situ enzymatic digestion, with the corresponding score, sequence coverage and matched peptides in the protein sequence

\begin{tabular}{|c|c|c|c|c|c|}
\hline Protein & $\begin{array}{l}\text { Match } \\
\text { score }\end{array}$ & $\begin{array}{l}\text { Mass } \\
(\mathrm{Da})\end{array}$ & Databank & $\begin{array}{l}\text { Sequence } \\
\text { coverage }\end{array}$ & $\begin{array}{l}\text { Peptides (red) matched } \\
\text { in the proteins sequence }\end{array}$ \\
\hline $\begin{array}{c}\text { Chordin-Like } \\
\text { Protein } 1 \\
\text { Precursor } \\
\text { (Neuralin-1): } \\
\text { Neurogenesin-1 }\end{array}$ & 39 & 50526 & Swissprot & 48 & $\begin{array}{lll}\text { MEGIKYIASL } & \text { VFFFVFLEAS } & \text { KTEPVKHSET } \\
\text { YCMFQDKKYR } & \text { VGEKWHPYLE } & \text { PYGLVYCVNC } \\
\text { ICSENGNVLC } & \text { SRVRCPTLHC } & \text { LSPVHIPHLC } \\
\text { CPRCPDSLPP } & \text { MNSKVTSKSC } & \text { EYNGTTYQHG } \\
\text { ELFIAEGLF } & \text { NRQPNQCSQC } & \text { SCSEGNVYCG } \\
\text { LKTCPKLTCA } & \text { FPVSVPDSCC } & \text { RVCRGDGELS } \\
\text { WEHSDADIFR } & \text { QPANREARHS } & \text { YLRSPYDPPP } \\
\text { SRQAGGLPRF } & \text { AGSRSHRGAV } & \text { IDSQQASGTI } \\
\text { VQIVINNKHK } & \text { HGQVCVSNGK } & \text { TYSHGESWHP } \\
\text { NLRAFGIVEC } & \text { VLCTCNVTKQ } & \text { ECKKIHCPNR } \\
\text { YPCKYPQKLD } & \text { GKCCKVCPEE } & \text { PPSQNFDSKG } \\
\text { SFCGEETMPV } & \text { YEAVLVEDGE } & \text { TARKVALETE } \\
\text { KPPQVEVHVW } & \text { TIRKGILQHF } & \text { HIEKISKEMF } \\
\text { GGLHHFKLVT } & \text { RTTMNQWKIF } & \text { AEGEAQLSQM } \\
\text { CSSRVCRTEL } & \text { EDLVQVLYLE } & \text { RPEKDHCR }\end{array}$ \\
\hline $\begin{array}{l}\text { Neuromodulin } \\
\text { (Axonal } \\
\text { Membrane } \\
\text { Protein GAP-43) }\end{array}$ & 24 & 23589 & Swissprot & 47 & $\begin{array}{ll}\text { MLCCMRRTKQ VEKNDEDQKI } & \text { EQDGVKPEDK } \\
\text { AHKAATKIQA SFRGHITRKK } & \text { LKDEKKGDAP } \\
\text { AAEAEAKEKD DAPVADGVEK } & \text { KEGDGSATTD } \\
\text { AAPATSPKAE } & \text { EPSKAGDAPS } \\
\text { PSEKKGEGDAA } \\
\text { PAKEESKAE TESAAKATTD NSPSSKAEDG } \\
\text { AAQPPTETAE SSAATDAAA TTPAAEDAAK } \\
\text { RQDEGKEDPE ADQEHA }\end{array}$ \\
\hline $\begin{array}{l}\text { Dystrophin- } \\
\text { Associated } \\
\text { Glycoprotein) } \\
\text { (43DAG) }\end{array}$ & 50 & 41643 & NCBI & 47 & $\begin{array}{lll}\text { MQPASDSRWR } & \text { VTGLQGSEPT } & \text { QTLAHSGFLS } \\
\text { EGWRGRGKAW } & \text { PSQGVSPTPV } & \text { PERKRGLRRA } \\
\text { KMAAAAAAAA } & \text { ATEQQGSNGP } & \text { VKKSMREKAV } \\
\text { ERRNVNKEHN } & \text { SNFKAGYIPI } & \text { DEDRLHKTGL } \\
\text { RGRKGNLAIC } & \text { VIVLLFILAV } & \text { INLLITLVIW } \\
\text { AVIRIGPNGC } & \text { DSLEFHESGL } & \text { LRFKQVSDMG } \\
\text { IIHPLYKSTV } & \text { GGRRNENLVI } & \text { TGNNQPIVFQ } \\
\text { QGTTKLSVEK } & \text { NKTSITSDIG } & \text { MQFFDPRTQN } \\
\text { ILFSTDYETH } & \text { EFHLPSGVKS } & \text { LNVQKASTER } \\
\text { ITSNATSDLN } & \text { IKVDGRAIVR } & \text { GNEGVFIMGK } \\
\text { TIEFHMRGDV } & \text { ELKAENSIIL NGTVMVSTR } \\
\text { LPSSSGGDQS } & \text { GSGDWVRKL } & \text { CMCADGTLFK } \\
\text { VOVTSHNMGC } & \text { OVSDNPCGNT } & \text { H }\end{array}$ \\
\hline Vimentin & 54 & 53569 & $\mathrm{NCBI}$ & 42 & $\begin{array}{lll}\text { STRSVSSSSY } & \text { RRMFGGSGTS } & \text { SRPSSNRSYV } \\
\text { TTSTRTYSLG } & \text { SALRPSTSRS } & \text { LYSSSPGGAY } \\
\text { VTRSSAVRLR } & \text { SSMPGVRLLQ } & \text { DSVDFSLADA } \\
\text { INTEFKNTRT } & \text { NEKVELQELN } & \text { DRFANYIDKV } \\
\text { RFLEQQNKIL } & \text { LAELEQLKG } & \text { GKSRLGDLYE } \\
\text { EEMRELRRQV } & \text { DQLTNDKARV } & \text { EVERDNLAED } \\
\text { IMRLREKLQE } & \text { EMLQREEAES } & \text { TLQSFRQDVD } \\
\text { NASLARLDLE } & \text { RKVESLQEEI } & \text { AFLKKLHDEE } \\
\text { IQELQAQIQE } & \text { QHVQIDVDVS } & \text { KPDLTAALRD } \\
\text { VRQQYESVAA } & \text { KNLQEAEEWY } & \text { KSKFADLSEA }\end{array}$ \\
\hline
\end{tabular}




\begin{tabular}{|c|c|c|c|c|c|}
\hline & & & & & 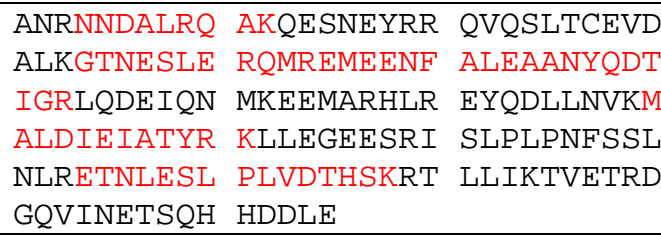 \\
\hline $\begin{array}{l}\text { Ul-R-BJ2-bqp-d- } \\
\text { 02-0-Ul.s1 UI-R- } \\
\text { BJ2 Rattus } \\
\text { Norvegicus } \\
\text { cDNA Clone }\end{array}$ & 58 & 17842 & EST & 83 & $\begin{array}{l}\text { RSPSRQSW_M RMPCHRSAKA TTLCAWCSPA } \\
\text { ATRTWTLCEL CGPQEISRHR WTLQWPSMTC } \\
\text { LWSWTF_ILS TRKPPCGSWT CAPLCCPKLR } \\
\text { NFCRASMRAM SRLGVPPSS_ SCSGSYPSSL } \\
\text { TFWQPRPLWV WTSAERRGCI SVDSASSSSR } \\
\text { ASVASSRAGR V_AA }\end{array}$ \\
\hline $\begin{array}{l}\text { UI-R-DZ1-cnf-g- } \\
\text { 02-0-Ul.s1 } \\
\text { NCl_CGAP_DZ1 } \\
\text { Rattus } \\
\text { norvegicus } \\
\text { cDNA clone } \\
\end{array}$ & 54 & 16280 & EST & 78 & $\begin{array}{l}\text { NGTMSPAITS } \text { CPSHVKRAQW PVENPQRWSM } \\
\text { PEPLGRRKIA MRSAPWCGTS VLRALSSAMC } \\
\text { PPSGVSPVGT GKSLESLAQT PTPTSTGYRS } \\
\text { GA_DPHGGAA PAWPTERSFH NVPRMLSPAA } \\
\text { SHADRASHST WCLLVAFCHI RNPLKKEKKK } \\
\text { KK }\end{array}$ \\
\hline $\begin{array}{l}\text { AGENCOURT_2 } \\
8540227 \\
\text { NIH_MGC_249 } \\
\text { Rattus } \\
\text { norvegicus } \\
\text { cDNA clone }\end{array}$ & 52 & 26005 & EST & 57 & $\begin{array}{lll}\text { SAEMVDSLQT } & \text { SPKSQWCAEP } & \text { R_PEVVFCLS } \\
\text { HLEGCIDVVW } & \text { NSCPLXWTGL } & \text { PD_SHMG_SG } \\
\text { LHGPSSCWPA } & \text { GCPSSCSPS_ } & \text { FARWSVS_TL } \\
\text { PPARSCQNGW } & \text { LCHVASAGAS } & \text { PRRTHPAPCP } \\
\text { HRGSIPVRLG } & \text { R_MYTEHLSG } & \text { PSEGADCGF } \\
\text { TQTRRRQPSV } & \text { PSGSCPSWHR } & \text { SQ_RCQSDPR } \\
\text { PRYSGPQWAQ } & \text { HVRG_VSSLS } & \text { SGTSAFRWG } \\
\text { MVPQSQASW_- SAAVRPAVEL } & \text { CSCRGVADGC } \\
\text { RTCGWCNPPG } & \text { PRS }\end{array}$ \\
\hline
\end{tabular}


Table 3: Differential protein found after trypsic digestion by comparing 6-OHDA FFPE tissues to control FFPE tissues of rat brains using either MALDI-MS direct analysis or nanoLC-nanoESI-IT MS on analogue zones

\begin{tabular}{|c|c|c|c|c|c|c|c|}
\hline Markers & Protein & $\begin{array}{c}\mathrm{m} / \mathbf{z} \\
\text { MDA* }^{*}\end{array}$ & $\begin{array}{l}\mathrm{m} / \mathrm{z} \\
\mathrm{ESI}\end{array}$ & $\begin{array}{c}\text { Mascot } \\
\text { score } \\
(\%)\end{array}$ & $\begin{array}{c}\text { Detected } \\
\text { on heathy } \\
\text { zone } \\
\text { (number) }\end{array}$ & $\begin{array}{c}\text { Detected on } \\
\text { dammaged } \\
\text { zone } \\
\text { (number) }\end{array}$ & $\begin{array}{c}\text { Known in } \\
\text { Parkinson's } \\
\text { Disease } \\
\text { literature }\end{array}$ \\
\hline \multirow{3}{*}{ Down-regulated } & $\begin{array}{c}\text { Trans elongation } \\
\text { Factor } 1 \text { (eEF1) }\end{array}$ & 1025.5 & 1025.8 & 66 & $3 / 5$ & $0 / 5$ & \\
\hline & $\begin{array}{l}\text { Hexokinase } \\
(2-7-1-1)\end{array}$ & 1399.9 & 1400.5 & 76 & $3 / 5$ & $0 / 5$ & 33 \\
\hline & $\begin{array}{l}\text { Neurofilament M } \\
\text { Protein }\end{array}$ & 1770.6 & 1770.8 & 57 & $4 / 5$ & $0 / 5$ & 5 \\
\hline \multirow{5}{*}{ Up-regulated } & Peroxidoxin 6 & 1499.9 & 1498.8 & 65 & $0 / 5$ & $4 / 5$ & 5 \\
\hline & F1 ATPase & & 2007.3 & 81 & $0 / 5$ & $4 / 5$ & 18 \\
\hline & $\alpha$-Enolase & 3062.9 & 3063.6 & 62 & $0 / 5$ & $3 / 5$ & 34 \\
\hline & Ubc-Ubiquitin & 647.4 & & 78 & $0 / 5$ & $4 / 5$ & 11 \\
\hline & CRMP2 & 1083 & 1083.6. & 70 & $0 / 5$ & $4 / 5$ & \\
\hline
\end{tabular}

*MDA: MALDI Direct Analysis MS 
Table 4: Data for the identification CRMP2 protein ( $\mathrm{MW}_{\mathrm{avg}}=62270.62$ u., Score 245$)$ in 6-OHDA injected rat brain FFPE tissues after trypsin digestion and nano-LC nanoESI-IT MS and MS/MS experiments a) peptide mass fingerprint identification data b) peptide sequence tag (MS/MS) identification data for the M/z 508.59 ion assigned as fragment SAAEVIAQAR of CRMP2 and c) CRMP2 protein (Rattus norvegicus, P47492) sequence. Red indicates parts of the sequence found in the nanoLC-nanoESI-IT MS experiments, in blue those obtained during MALDI direct analysis and in purple the common ones.

a)

\begin{tabular}{ccccl}
\hline $\begin{array}{c}\text { Observed } \mathbf{~ M / z} \\
\left([\mathbf{M}+\mathbf{H}]^{+},[\mathbf{M}+\mathbf{2 H}]^{2+}\right. \\
\left.\text { or }[\mathbf{M + 3 H}]^{3+}\right)\end{array}$ & $\begin{array}{c}\text { Experimental } \\
\mathbf{M w} \\
\text { monoisotopic }\end{array}$ & $\begin{array}{c}\text { Calculated } \\
\mathbf{M w} \\
\text { monoisotopic }\end{array}$ & $\begin{array}{c}\text { Peptide } \\
\text { Position }\end{array}$ & \multicolumn{1}{c}{ Peptide } \\
\hline $\mathbf{5 0 8 . 5 9 0}$ & $\mathbf{1 0 1 5 . 1 6 6}$ & $\mathbf{1 0 1 4 . 5 4 6}$ & $\mathbf{2 5 9 - 2 6 8}$ & SAAEVIAQAR \\
543.064 & 1084.114 & 1083.629 & $441-451$ & GSPLVISQGK \\
562.215 & 1683.623 & 1681.863 & $452-467$ & IVLEDGTLHVTEGSGR \\
571.065 & 1140.116 & 1139.601 & $472-480$ & KPFPDFVYK \\
571.066 & 1710.178 & 1710.913 & $468-480$ & YIPRKPFPDFVYK \\
648.020 & 1294.025 & 1293.686 & $64-75$ & MVIPGGIDVHTR \\
675.321 & 674.314 & 674.360 & $566-572$ & ANITSLG \\
834.047 & 2499.119 & 2498.160 & $271-293$ & GTVYGEPITASLGTDGSHYWSK \\
863.482 & 1724.950 & 1724.804 & $375-390$ & MDENQFVAVTSTNAAK \\
896.971 & 1791.928 & 1791.827 & $346-361$ & DNFTLIPEGTNGTEER \\
956.396 & 1910.777 & 1910.015 & $174-189$ & FQLTDSQIYEVLSVIR \\
959.045 & 1916.076 & 1914.957 & $401-418$ & ISVGSDADLVIWDPDSVK \\
\hline
\end{tabular}

b)

\begin{tabular}{|c|c|c|}
\hline \multicolumn{3}{|c|}{$\begin{array}{c}\text { Peptide Sequence SAAEVIAQAR } \\
\text { M/z observed } 508.590\left(\left[\mathrm{M}+\mathrm{H}^{+}\right)\right. \\
\text {Ion Score } 63\end{array}$} \\
\hline & $\begin{array}{l}\text { Matched } \\
\text { ions } \mathrm{M} / \mathrm{z}\end{array}$ & Ion assignment \\
\hline 1 & 229.129 & {$\left[\mathrm{y}_{2}-17\right]^{+}$} \\
\hline 2 & 230.113 & $\mathrm{~b}_{3}^{+}$ \\
\hline 3 & 246.156 & $\mathrm{y}_{2}^{+}$ \\
\hline 4 & 341.146 & {$\left[b_{3}-18\right]^{+}$} \\
\hline 5 & 359.156 & $\mathrm{~b}_{4}^{+}$ \\
\hline 6 & 374.215 & $\mathrm{y}_{3}^{+}$ \\
\hline 7 & 440.214 & {$\left[b_{5}-18\right]^{+}$} \\
\hline 8 & 445.252 & $\mathrm{y}_{4}^{+}$ \\
\hline 9 & 458.224 & $\mathrm{~b}_{5}^{+}$ \\
\hline 10 & 553.298 & {$\left[b_{6}-18\right]^{+}$} \\
\hline 11 & 558.336 & $\mathrm{y}_{5}^{+}$ \\
\hline 12 & 571.309 & $\mathrm{~b}_{6}^{+}$ \\
\hline 13 & 642.346 & $\mathrm{~b}_{7}^{+}$ \\
\hline 14 & 657.404 & $\mathrm{y}_{6}^{+}$ \\
\hline 15 & 752.394 & {$\left[b_{8}-18\right]^{+}$} \\
\hline 16 & 769.420 & {$\left[y_{7}-17\right]^{+}$} \\
\hline 17 & 770.404 & $\mathrm{~b}_{8}^{+}$ \\
\hline 18 & 840.457 & {$\left[\mathrm{y}_{8}-17\right]^{+}$} \\
\hline 19 & 841.441 & $\mathrm{~b}_{9}^{+}$ \\
\hline 20 & 857.484 & $\mathrm{y}_{8}^{+}$ \\
\hline
\end{tabular}

c)

\begin{tabular}{|cllll|}
\hline 1 & MSYQGKKNIP & RITSDRLLIK & GGKIVNDDQS & FYADIYMEDG \\
41 & LIKQIGENLI & VPGGVKTIEA & HSRMVIPGGI & DVHTRFQMPD \\
81 & QGMTSADDFF & QGTKAALAGG & TTMIIDHVV & EPGTSLLAAF \\
121 & DQWREWADSK & SCCDYSLHVD & ITEWHKGIQE & EMEALVKDHG \\
161 & VNSFLVYMAF & KDRFQLTDSQ & IYEVLSVIRD & IGAIAQVHAE \\
201 & NGDIIAEEQQ & RILDLGITGP & EGHVLSRPEE & VEAEAVNRSI \\
241 & TIANQTNCPL & YVTKVMSKSA & AEVIAQARKK & GTVVYGEPIT \\
281 & ASLGTDGSHY & WSKNWAKAAA & FVTSPPLSPD & PTTPDFLNSL \\
321 & LSCGDLQVTG & SAHCTFNTAQ & KAVGKDNFTL & IPEGTNGTEE \\
361 & RMSVIWDKAV & VTGKMDENQF & VAVTSTNAAK & VFNLYPRKGR \\
401 & ISVGSDADLV & IWDPDSVKTI & SAKTHNSALE & YNIFEGMECR \\
441 & GSPLVVISQG & KIVLEDGTLH & VTEGSGRYIP & RKPFPDFVYK \\
481 & RIKARSRLAE & LRGVPRGLYD & GPVCEVSVTP & KTVTPASSAK \\
521 & TSPAKQQAPP & VRNLHQSGFS & LSGAQIDDNI & PRRTTQRIVA \\
561 & PPGGRANITS & LG & & \\
& & & & \\
\hline
\end{tabular}



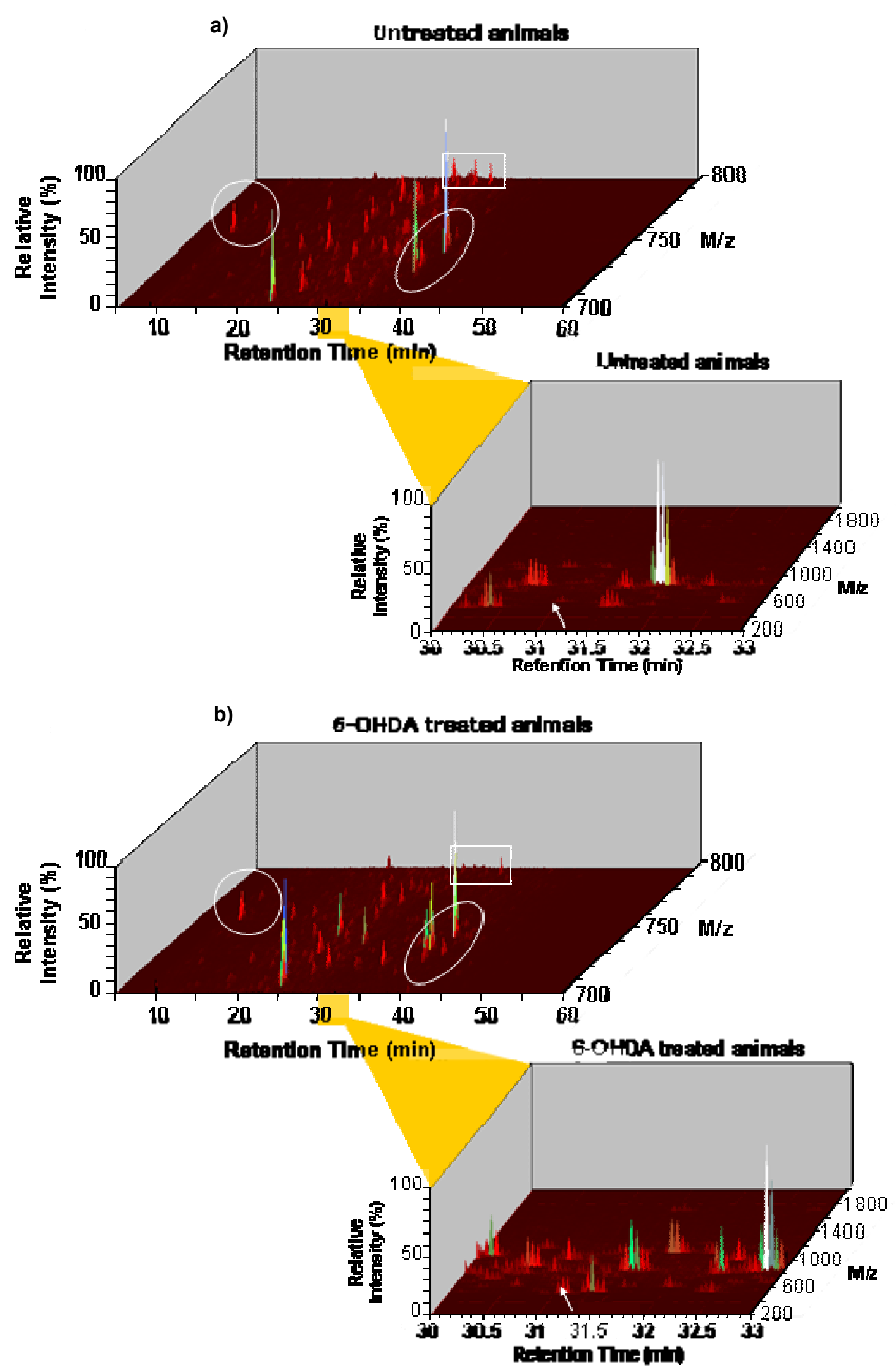

Figure 1 


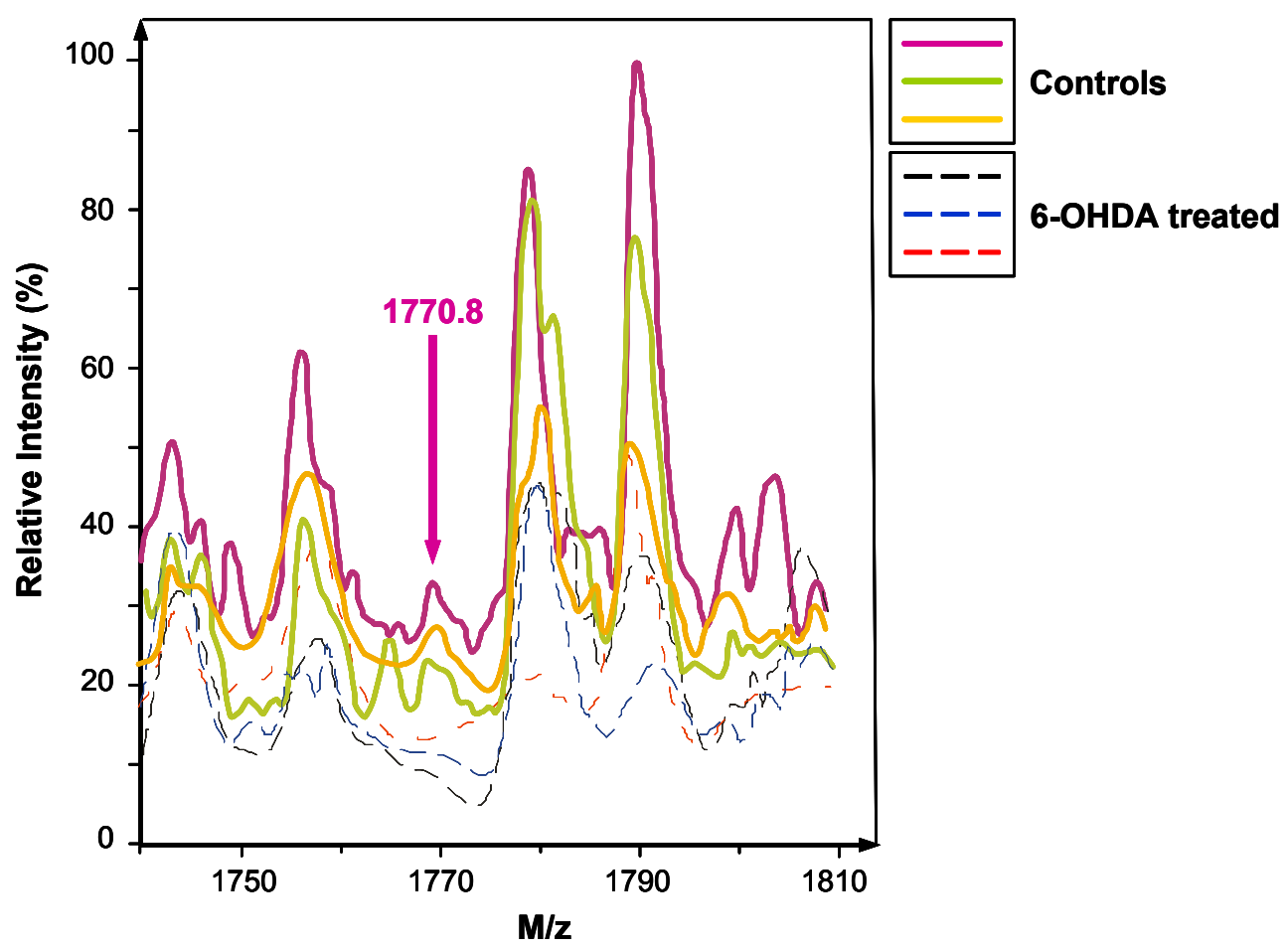

Figure 2 


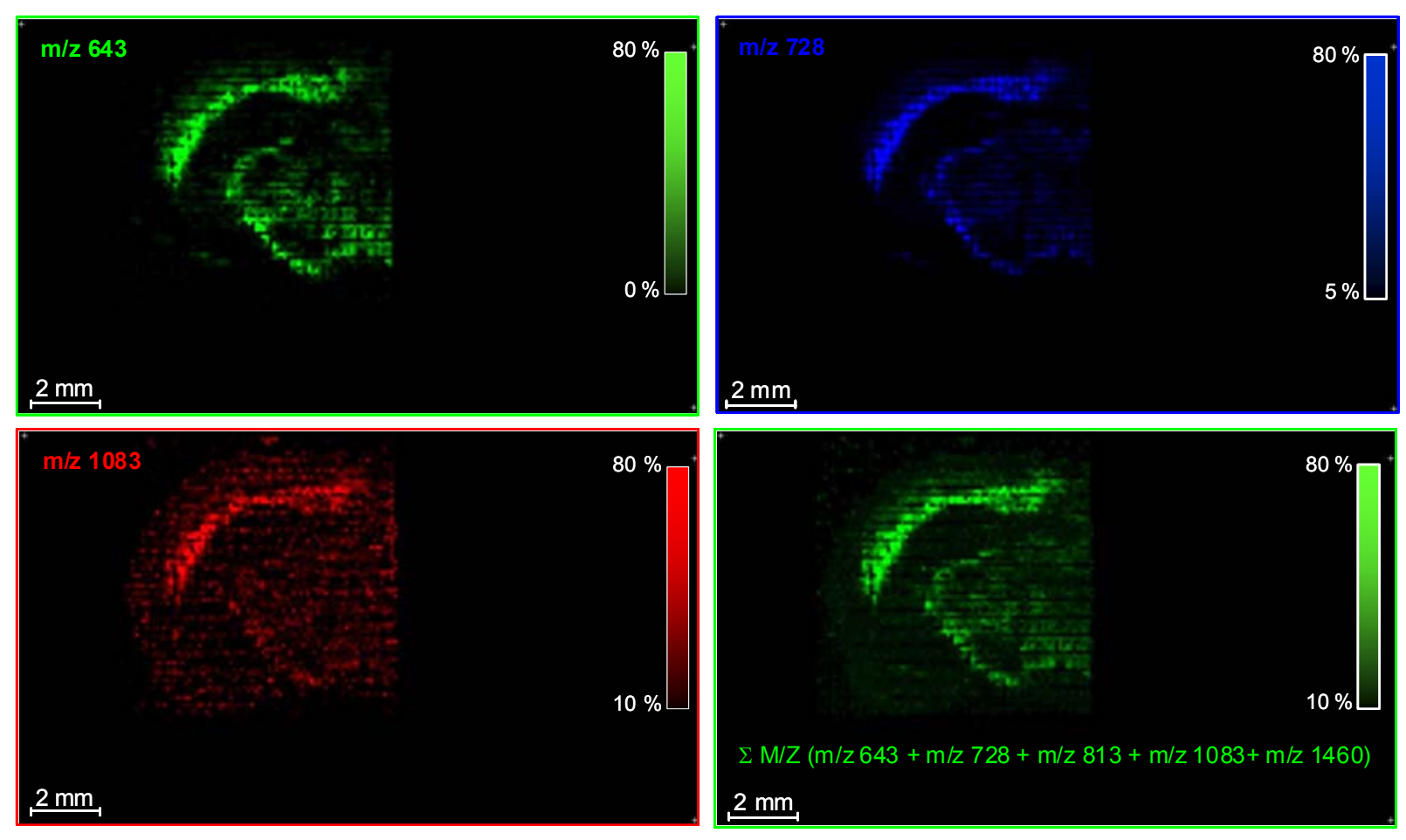

Figure 3 

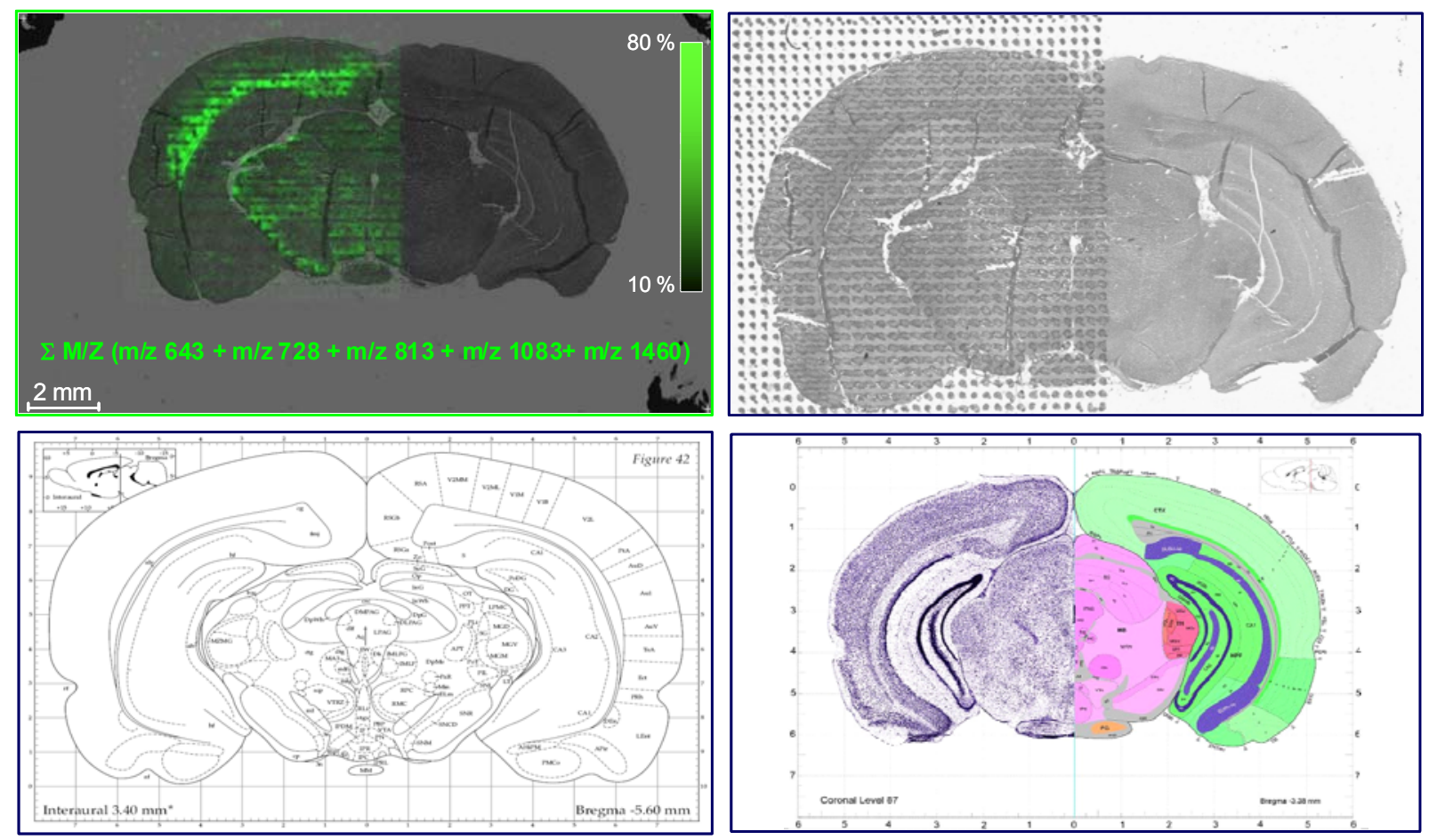

Figure 4 


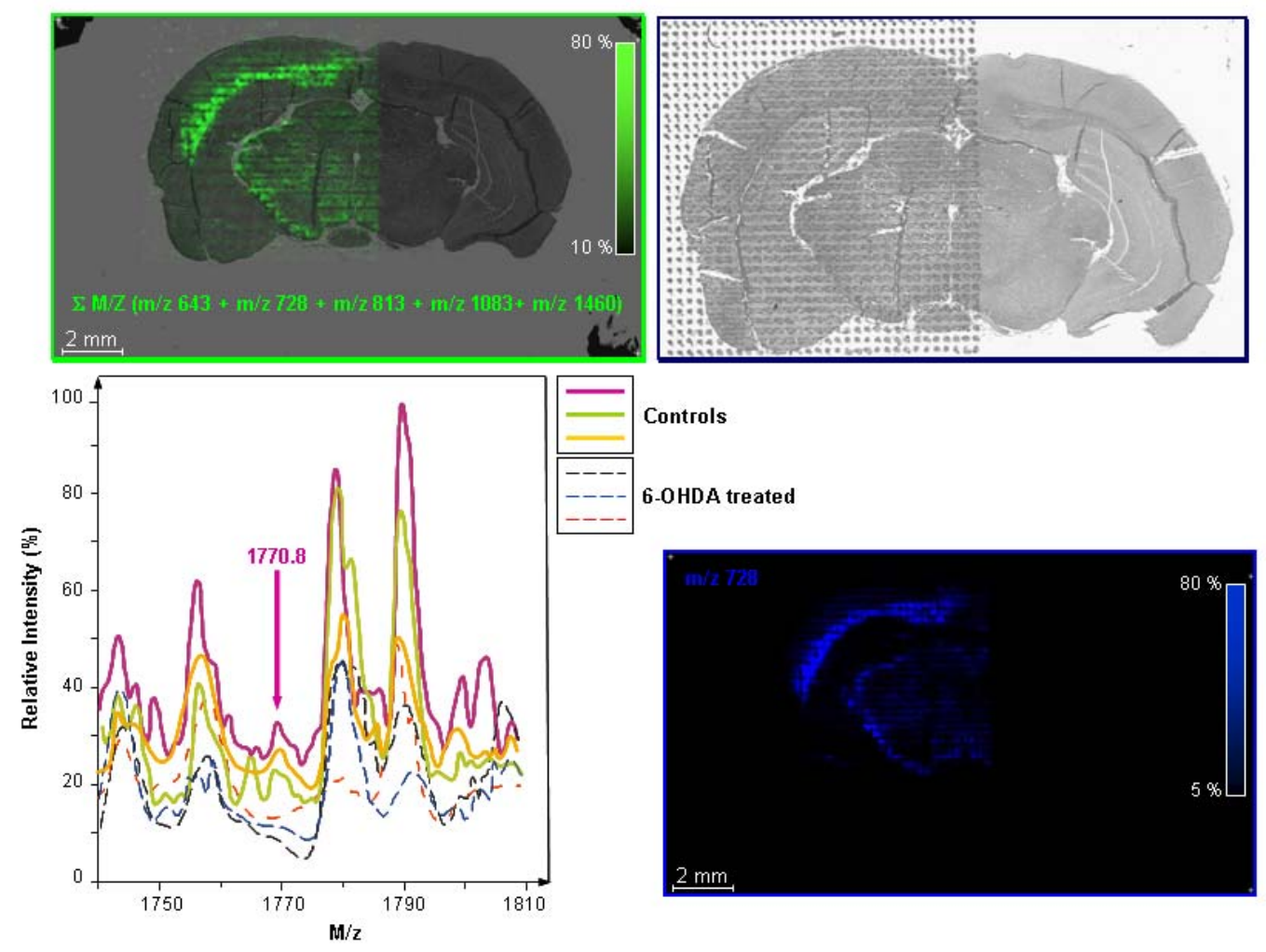

Synopsis 